\title{
Lower extremity reconstruction: epidemiology, management and outcomes of patients of the Federal District North Wing Regional Hospital
}

\section{Reconstrução de membros inferiores: perfil, manejo e evolução dos pacientes do Hospital Regional da Asa Norte do Distrito Federal}

Jefferson lessa Soares Macedo, tCBC-DF1,2; Simone Corréa Rosa 1,3; Daniel lobo Botelho1; Clendes Pereira dos Santos'; Murilo Neves de Queiroz²; Tabatha Gonçalves Andrade Castelo Branco Gomes².

\begin{abstract}
A B S T R A C T
Objective: to evaluate the management of lower limbs complex traumatic injuries by analyzing their characteristics, types, conduct and evolution, with emphasis on surgical treatment. Methods: we conducted a prospective study of patients treated by Plastic Surgery at a regional hospital of the Federal District during a one-year period. We collected data through serial evaluations and telephone contact records. Results: we studied 40 patients, with a mean age of 25.6 years, predominantly male (62.5\%). The most frequent wounds were of the distal third of the lower limb (37.5\%). Bone or tendon exposures occurred in 55\% had and there was a 35\% rate of exposed lower limb fractures. The treatments employed were skin grafting (57.5\%), local fasciocutaneous flap (15\%), muscle flap (12.5\%), cross-leg fasciocutaneous flap, reverse sural flap (12.5\%) and microsurgical flap (2.5\%). Short-term evaluation showed that 35 patients had excellent or good results (87.5\%), four had a regular result (10\%), and one had an unsatisfactory result (2.5\%). In the long term, of the 18 patients who answered the questionnaire, ten resumed walking, even with support, in the first three months after surgery (55.6\%). Conclusion: young men involved in motorcycle accidents during leisure time represented the profile of patients with lower limb trauma requiring surgical reconstruction; the distal third of the leg was the most affected region. Grafting was the most used technique for reconstruction and postoperative functional evaluation showed that, despite complex lesions, most patients evolved with a favorable healing process and successful functional evolution.
\end{abstract}

Keywords: Lower Extremity. Wounds and Injuries. Injury Severity Score. Surgery, Plastic.

\section{INTRODUCTION}

$\mathrm{T}$ rauma is one of the main causes of preventable death and one of the main mechanisms of complex wound formation affecting young adults and a large part of the economically active population?.

Lower limb wounds reach a variable spectrum, and are generally caused by high-energy trauma, with extensive skin loss and impaired tissue viability, associated with amputations of limbs or fingers, lacerations, crushing and exposures of noble tissues ${ }^{1}$. Over the last 30 years, advances in reconstructive surgery, such as the recognition and use of pediculated fasciocutaneous/muscular flaps and the introduction of microsurgery have broadened the therapeutic arsenal of the plastic surgeon in the treatment of traumatic injuries $^{1-6}$. In addition, the lower limbs, especially the leg and foot, have some characteristics that make it difficult to treat wounds in this region, such as: thin skin coating; scarce subcutaneous tissue; terminal arterial vascularization; venous return made difficult by the orthostatic position; and of heavy loads for most of the time ${ }^{7,8}$

The evaluation, follow-up and decision of surgical treatment of these complex lesions are conducts taken by a multidisciplinary team, with the fundamental participation of the plastic surgeon. Functional recovery should always be sought, regardless of the proposed treatment, reconstruction or amputation ${ }^{8,9}$.

The objective of this study is to present the epidemiological profile, treatment and evolution of patients sustaining lower limbtrauma treated at the Plastic

1 - North Wing Regional Hospital, Plastic Surgery Service, Brasília, DF, Brazil. 2 - School of Health Sciences, Medicine Course, Brasília, DF, Brazil. 3 University of Brasilia, Postgraduate Course in Health Sciences, Brasilia, DF, Brazil. 
Surgery Service of the North Wing Regional Hospital (HRAN), Brasília-DF.

\section{METHODS}

This is a prospective study of patients victims of lower limbtrauma admitted to the HRAN, who underwent surgical reconstruction of the lower limbs due to loss of skin cover, with and without bone exposure, from January to December 2011. Patients were admitted to the Plastic Surgery Service by direct referral from the emergency room or outpatient clinic, but only after clinical / surgical control of their fractures by orthopedics, general surgery and / or other services. All patients underwent surgical treatment of their wounds, from debridement to complete coverage of defects. None of them was submitted to second intention healing, to the use of vacuum dressing or to the use of acellular dermis replacement.

We evaluated the following variables: gender, age, trauma etiology, presence and location fractures, characteristics of the substance loss, presence of bone exposure and type of treatment established in lower limb reconstructions.

The initial basic treatment of open fractures was performed, on average, in the first 24 to 48 hours after the trauma, and consisted in all cases of mechanical and surgical cleaning associated with transskeletal traction, bipolar fixation, immobilization with a cast material, or external fixation. In cases of closed fractures, patients received plates and screws, osteosynthesis with crossed Kirschner wires, or bipolar fixation.

In the immediate postoperative period, patients were immobilized with cruropodal plaster cast. The first dressing was performed on the fifth postoperative day and stitches were removed around the 15th day. In the donor area of the skin graft, we used vaseline gauze and $10 \%$ zinc oxide cream to accelerate the healing process.

We performed the short-term postoperative assessment (one to two months) by observing the cutaneous cover, classifying wound healing in: "Excellent": no graft or flap distress; "Good": suffering of up to a third of the graft or flap; "Regular": suffering from graft or flap up to one-third with signs of infection; or "Unsatisfactory": graft or flap loss greater than one-third".

We carried out the analysis of the long-term outcome, performed at least 48 months postoperatively, through telephone contact. Patients responded to a questionnaire based on Harris Score and Vancouver International Scale for scars ${ }^{10-12}$. The questionnaire included seven categories: use of support for ambulation, presence of claudication, distance that can walk, postoperative period in which began to walk, pain in the operated region and quality of the scar (presence of secretion and flexibility). To consider failure in the telephone contact, we made at least six calls on three different days.

We used The SPSS version 17.0 program for data compilation, graphics assembly and epidemiological analysis.

The study was approved by the Ethics in Research Committee of the State Department of Health of the Federal District (CAAE number: 47391715.6.0000.5553, opinion number: 1,167,841).

\section{RESULTS}

During the study period, there were 40 patients with complex wounds caused by trauma to the lower limbs. The mean age was 25.6 years, ranging from two to 56 years, with a predominance of the 20-29 age group. There was a predominance of males, representing $62.5 \%$ of the sample. Regarding etiology, motorcyclist accidents (52.5\%)were the most prominent,followed by run-over accidents (22.5\%). Regarding the place or circumstance, leisure time was the main moment of trauma, followed by work accidents (Table 1).

The mean wound time before the evaluation by the Plastic Surgery Team was one week. Measurements of the areas requiring treatment ranged from $3 \times 5 \mathrm{~cm}$ to $5 \times 12 \mathrm{~cm}$. Loss of substance from the distal third of the leg was the most frequent (37.5\%), followed by lesions of the middle and upper third, respectively. Regarding fractures or other orthopedic injuries, 35\% 
Table 1. Descriptive data of patients sustaining lower limb trauma attended at HRAN from January to December in 2011.

\begin{tabular}{lcc}
\hline & Number & $\%$ \\
\hline Gender & & \\
$\quad$ Male & 25 & $62.5 \%$ \\
$\quad$ Female & 15 & $37.5 \%$ \\
Origin & & \\
$\quad$ Federal District & 22 & $55 \%$ \\
$\quad$ Outside the Federal District & 18 & $45 \%$ \\
Age group & & \\
0-19 years & 10 & $25 \%$ \\
20-29 years & 20 & $50 \%$ \\
$\quad 30-39$ years & 5 & $12.5 \%$ \\
$\quad>39$ years & 5 & $12.5 \%$ \\
Type of accident & & \\
$\quad$ Motorcycle & 21 & $52.5 \%$ \\
Run-over & 9 & $22.5 \%$ \\
Agricultural Machine & 4 & $10 \%$ \\
Automotive & 3 & $7.5 \%$ \\
$\quad$ Fall & 2 & $5.0 \%$ \\
Fire arm & 1 & $2.5 \%$ \\
Trauma context & & \\
Leisure & 18 & $45 \%$ \\
Work & 7 & $17.5 \%$ \\
Other & 15 & $37.5 \%$ \\
\hline
\end{tabular}

of the patients did not present them; 35\% suffered tibial/fibular fracture; $7.5 \%$ suffered a femoral fracture; and $22.5 \%$ suffered other fractures or orthopedic injuries such as dislocation, tendon rupture and patellar fracture. Bone exposure occurred in $55 \%$ of patients and the other $45 \%$ had only soft tissue loss, without bone or tendon exposure (Table 2).

The treatment proposed for each case was in agreement with the presence or absence of bone exposure. We used total or partial skin graft for the wounds with good granulation tissue without exposure of noble structures, representing $57.5 \%$ of the procedures (Figure 1). We The flaps for major substance loss or exposure of noble structures, divided into: fasciocutaneous flap (15\%), muscular flap of the medial head of the gastrocnemius (12.5\%), reverse sural fasciocutaneous flap (7.5\%), cross-leg fasciocutaneous flap (5\%) and microsurgical anterolateral thigh fasciocutaneous flap (2.5\%) (Figure 2, Table 3).
The short-term evaluation of the cutaneous cover showed that 35 patients had excellent or good results (87.5\%), four had a regular result (10\%) and one had an unsatisfactory result (2.5\%).

Regarding the long-term evaluation, of the 18 patients who answered the questionnaire, ten started walking, even with support, in the first three months after surgery $(55.6 \%)$, three in the second trimester $(16.7 \%)$, two in the second semester $(11.1 \%)$ and the other three after one year (16.7\%). Among the patients who answered the questionnaire, none was unable to walk. We assessed mobility by dividing the patients into five groups: wheelchair; walking with the aid of crutches - two or one -; walking with the aid of a walking stick; walking without assistance. Four years after the surgical procedure to cover the loss of leg substance due to trauma, $88.9 \%$ of the patients walked without assistance and $11.1 \%$ with the help of a walking stick or a crutch. Regarding claudication, $44.4 \%$ of the patients reported no pain or only mild pain without functional impairment, 38.9\% reported moderate claudication, which made it impossible to run, and $16.7 \%$ reported severe claudication, with intense pain. We measured the distance the patients could walk in blocks, with $22.2 \%$ being able to walk unlimited distances, 50\% able to walk long distances (more than three blocks), $16.7 \%$, a maximum of two or three blocks, and only $11.1 \%$ could walk only indoors (Table 4).

Table 2. Characteristics of the substance loss area of patients sustaining lower limb trauma attended at HRAN from January to December in 2011.

\begin{tabular}{lcc}
\hline & Number & $\%$ \\
\hline $\begin{array}{l}\text { Substance loss área of leg } \\
\text { Proximal 1/3 }\end{array}$ & 12 & $30 \%$ \\
$\quad$ Medium 1/3 & 13 & $32.5 \%$ \\
$\quad$ Distal 1/3 & 15 & $37.5 \%$ \\
Bone exposure & & \\
$\quad$ Yes & 22 & $55 \%$ \\
$\quad$ No & 18 & $45 \%$ \\
Presence of open fracture & & \\
$\quad$ Yes & 15 & $37.5 \%$ \\
$\quad$ No & 25 & $62.5 \%$ \\
\hline
\end{tabular}




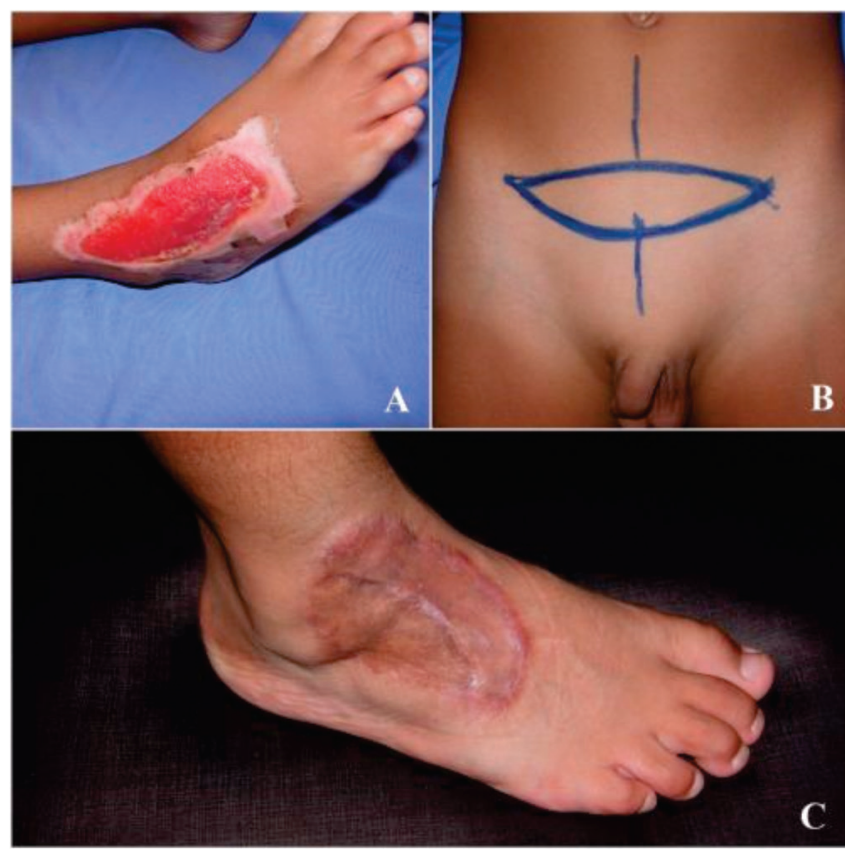

Figure 1. A) An 8-year-old child who was a run-over victim, with loss of substance on the back of the right foot, without bone or tendon exposure. B) Skin graft donor area. C) Two months after skin graft on the foot dorsum.

Only one patient reported severe pain in the reconstructed region, with serious limitations to daily activities.Five patients reported moderate, tolerable pain, and seven, occasional pain, without compromising activities. Five patients reported no pain after reconstruction of the lesion. We evaluated the scars in two aspects: presence of secretion and flexibility in the region. Fifteen patients reported dry scarring (83.3\%) and three patients remained with secretion outflow (16.7\%). Regarding flexibility, 16 patients (88.9\%) reported some movement limitation and only two reported no functional limitation due to the scar (Table 4).

\section{DISCUSSION}

The treatment of wounds with loss of substance in lower limbs due to trauma, infection or vascular processes is a challenge to surgeons and often requires the use of specialized techniques to cover bones, tendons, nerves, vessels and osteosynthesis materials. In this study, we verified, by the mean age of 25.6 years of the victims of accidents involving the lower limbs, that this type of trauma mainly affects the part of the society
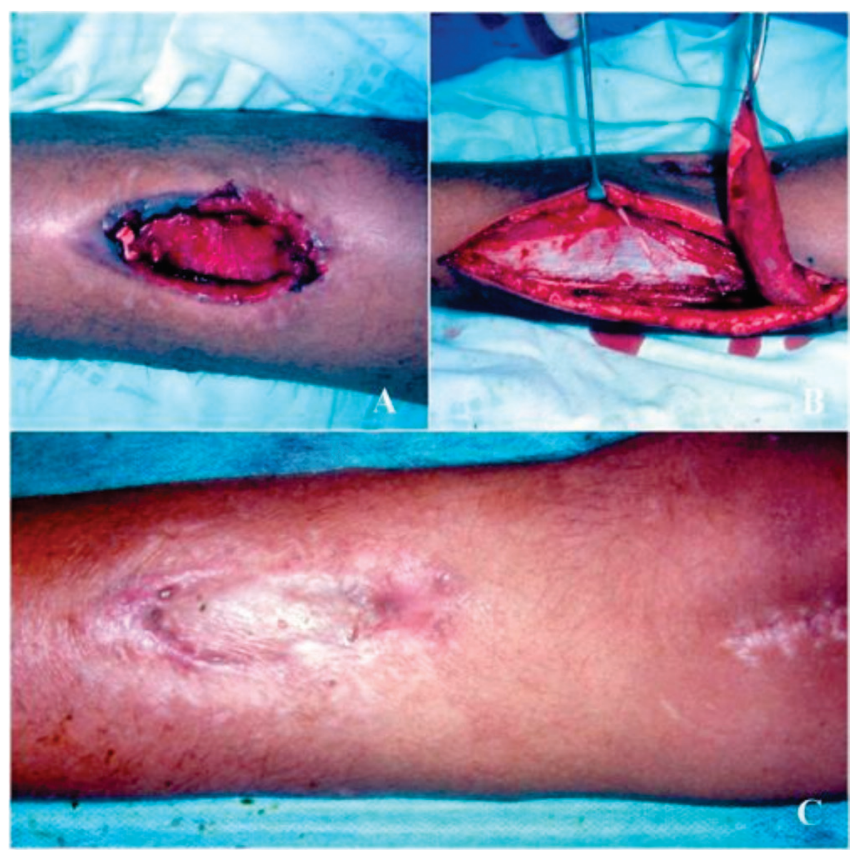

Figure 2. A) A 22-year-old patient victim of motorcycle accident, with bone exposure of the middle third of leg. B) Release of the medial head of the gastrocnemius muscle. Positioning of the muscular flap in the middle third of the leg. C) Skin graft over the Gastrocnemius medial head muscular flap, four months after the procedure.

that is economically active, bringing great socioeconomic impact. In addition, the major cause of these accidents is related to motorcycle use and pedestrian involvement (run-overs), which are gradually increasing in large cities and capitals, probably due to the increase in vehicular traffic and difficulties in adapting cities to high demand for public transportation, emphasizing the importance of public policies for traffic safety. This type of trauma has a high socioeconomic cost, leading to work absence for long periods, as has been verified in other studies ${ }^{13-15}$.

Although most of the patients involved in the traumas were in leisure time (45\%), a good portion of the injured $(17.5 \%)$ were in their working hours or in the homework path, which constitutes a work accident in Brazil.

The aim of surgical treatment in lower limb reconstructions is maximum limb functional recovery and return to work activities. Therefore, many studies advocate the early surgical coverage of complex wounds to avoid surgical site infection, ensure better bone remodeling, and shorten hospital stay ${ }^{16-18}$. Other studies have proposed a protocol that includes a series of surgical procedures from debridement to stabilization of the 
Table 3. Distribution of surgical treatment types and the level of the lesion in patients sustaining lower limb trauma attended at HRAN ${ }^{1}$, from January to December in 2011.

\begin{tabular}{|c|c|c|c|c|c|c|c|}
\hline Level of the injury & Graft $^{2}$ & $\begin{array}{l}\text { Muscle } \\
\text { flap }^{3}\end{array}$ & $\begin{array}{l}\text { Neighborhood } \\
\text { Flap }^{4}\end{array}$ & $\begin{array}{l}\text { Reverse sural } \\
\text { flap4" }\end{array}$ & Cross Leg ${ }^{5}$ & $\begin{array}{c}\text { Micro } \\
\text { surgical }^{6}\end{array}$ & Total \\
\hline Proximal $1 / 3$ & $\begin{array}{c}9 \\
(22.5 \%)\end{array}$ & $\begin{array}{c}3 \\
(7.5 \%)\end{array}$ & 0 & 0 & 0 & 0 & $\begin{array}{c}12 \\
(30 \%)\end{array}$ \\
\hline Medium 1/3 & $\begin{array}{c}4 \\
(10 \%)\end{array}$ & $\begin{array}{c}2 \\
(5 \%)\end{array}$ & $\begin{array}{c}5 \\
(12.5 \%)\end{array}$ & 0 & $\begin{array}{c}2 \\
(5 \%)\end{array}$ & 0 & $\begin{array}{c}13 \\
(32.5 \%)\end{array}$ \\
\hline Distal 1/3 & $\begin{array}{c}10 \\
(25 \%)\end{array}$ & 0 & $\begin{array}{c}1 \\
(2.5 \%)\end{array}$ & $\begin{array}{c}3 \\
(7.5 \%)\end{array}$ & 0 & $\begin{array}{c}1 \\
(2.5 \%)\end{array}$ & $\begin{array}{c}15 \\
(37.5 \%)\end{array}$ \\
\hline Total & $\begin{array}{c}23 \\
(57.5 \%)\end{array}$ & $\begin{array}{c}5 \\
(12.5 \%)\end{array}$ & $\begin{array}{c}6 \\
(15 \%)\end{array}$ & $\begin{array}{c}3 \\
(7.5 \%)\end{array}$ & $\begin{array}{c}2 \\
(5 \%)\end{array}$ & $\begin{array}{c}1 \\
(2.5 \%)\end{array}$ & \\
\hline
\end{tabular}

${ }^{1} H R A N=$ North Wing Regional Hospital; ${ }^{2}$ Sole skin grafting; ${ }^{3}$ Gastrocnemius medial head muscle flap; ${ }^{4}$ Neighbourhood Fasciocutaneous Flap; ${ }^{4}$ "Reverse Sural Fasciocutaneous Flap; ${ }^{5}$ Cross-leg Fasciocutaneous Flap; ${ }^{6}$ Microsurgical Anterolateral Thigh Flap.

wound, avoiding further complications ${ }^{19,20}$. In our study, performed in a hospital that does not have a polytrauma service, the majority of patients had outpatient admission for elective hospitalization at the Plastic Surgery Service for surgical programming, after clinical and hemodynamic stabilization, wound infection control, adequate debridement and fractures stabilization. Therefore, patients who were victims of traumatic or operative amputation were excluded.

The vascular conditions of the limb, both arterial and venous, should be carefully evaluated, both preoperatively and postoperatively. Circulatory diseases may be present and the trauma itself may render unfeasible apparently well-planned flaps.

The present study shows that $55 \%$ of the patients presented bone exposure, and 35\% had a tibial/ fibular fracture. We treated most patients with bone exposure with flaps for coverage, while patients who did not show bone exposure were treated with skin grafts. When they presented good granulation tissue without exposure of noble structures, the treatment of choice was partial or total skin grafting and outpatient monitoring of the healing process. In other situations, such as poor granulation tissue or exposure to noble structures such as bone, tendon, or vascular-nervous pedicles, the treatment consisted of fasciocutaneous or muscular flaps, according to the location of the wound bed, size, neighboring tissue structures and vascular preservation of the affected limb. We decided not to use negative pressure dressings because, despite reducing the bloody area and the complexity of the wound, they are contraindicated in wounds with exposure of blood vessels or nerves, bone or tendon.

The high grafting rate $(57.5 \%$ of the patients) used in this period is due to the characteristics of the lesions associated with the treatment of the wound bed, debridements and dressings, allowing the coverage with granulation tissue and good receptor bed for skin grafting. We used skin grafts in cases of substance loss that presented good granulation tissue, but without bone, tendon or vascular-nervous pedicles exposure. The formation of wound granulation tissue was stimulated with surgical debridements of the devitalized tissueand alginate or zinc oxidedressings.

The treatment with flaps obeyed guidelines already established in the literature, according to the area of substance loss, but there is still no consensus on the type of biological flap to be used, fasciocutaneous or myocutaneous ${ }^{21}$. This type of approach divides the leg in thirds to facilitate the choice of flap as a surgical option for wound coverage. The lower third of the leg had the most frequent substance loss, $37.5 \%$ of the patients, the surgical options being: skin grafts, reverse flow 
Table 4. Functional postoperative evaluation of patients victims of lower limbs trauma attended at HRAN from January to December in 2011, four years after the surgical procedure.

Support

None

Cane

Crutch

Claudication

None

Light, without hampering function (goes down 3 stairs, runs)

Moderate (can't run)

Severe

How far can you go

Unlimited

Far, more than three blocks

At most two or three blocks

Only indoors

How long took to walk after surgery (even with support)

Doesn't walk

First quarter

Second quarter

Second semester

After one year

Pain in the region

None

Casual, doesn't compromise activities

Moderate, tolerable pain, but makes concessions to pain

Sharp pain, serious limitation to activities SCAR

Dry

Secretion output

Flexibility in the scar area

With limitation of movement

Without limitation of movement fasciocutaneous flaps, and neighborhood fasciocutaneous flaps. We treated calcaneal and ankle substance losses (7.5\% each) with reverse sural fasciocutaneous flap and free microsurgical anterolateral thigh fasciocutaneous flap, respectively. The second most affected area of the leg was the middle third, totaling $32.5 \%$ of the cases, being treated with skin grafts, neighborhood fasciocutaneous flaps, cross-leg fasciocutaneous flaps or Gastrocnemius medial head muscular flap 9,22,23.

The Gastrocnemius medial head muscular flap is a good option to cover bony exposures of the upper and middle third of the leg and does not leave motor sequelae. We performed it in five patients (12.5\%). Similar results have been observed in other studies, including the concomitant use of the soleus muscle in cases of large bone exposure ${ }^{7,24}$. Distal reverse pedicle flaps, such as the reverse sural, have proved to be of great utility and versatility, especially for lesions of the distal third of the $\operatorname{leg}^{25}$. We used this flap in three patients.

The microsurgical flap remains one of the main options for limb reconstruction, especially in the lower third of the leg and foot, when there is no donor area for the reverse sural flap. However, microsurgical techniques require specialized training and there are no specialists in most hospitals to perform them. We used this technique in only one patient $(2.5 \%)$ with loss of foot substance and no donor area for the reverse sural flap.

We indicated cross-leg flaps in two patients (5\%) with substances losses from the lower third of the leg that did not present a donor area for the reverse sural flap or local fasciocutaneous flaps; also, microsurgery was not available at the time. The cross-leg flap has the disadvantage of prolonged immobilization and uncomfortable resting positions.

The repair surgery of lower limb wounds currently has an arsenal of procedures capable of solving most cases. Whenever possible, one should choosesimple and non-invasive procedures, to achieve an early rehabilitation of these patients.

Our study showed that young men involved in motorcycle accidents during leisure time represented the profile of patients with lower limb trauma who required 
surgical reconstruction, the distal third of the leg being the most affected region. Grafting was the most used technique for reconstruction and postoperative functional evaluation showed that, despite complex lesions, most patients evolved with a favorable healing process and successful functional evolution.

\title{
R E S U M O
}

\begin{abstract}
Objetivo: avaliar o tratamento de feridas traumáticas complexas de membros inferiores analisando suas características, tipos, condutas e evolução, com ênfase no tratamento cirúrgico. Métodos: estudo prospectivo de pacientes tratados pela Cirurgia Plástica em um hospital regional do Distrito Federal no período de um ano. Os dados foram coletados através de avaliações seriadas e registro de contatos telefônicos. Resultados: foram estudados 40 pacientes com média de idade de 25,6 anos, predominantemente homens (62,5\%). As feridas do terço distal do membro inferior foram mais frequentes (37,5\%). 55\% apresentavam exposições óssea ou tendinosa e 35\%, fraturas expostas do membro inferior. O tratamento foi enxerto de pele $(57,5 \%)$, retalho fascio-cutâneo local (15\%), retalho muscular $(12,5 \%)$, retalho fascio-cutâneo de perna cruzada, retalho sural reverso $(12,5 \%)$ e retalho microcirúrgico (2,5\%). A avaliação em curto prazo evidenciou que 35 pacientes tiveram resultado excelente ou bom (87,5\%), quatro tiveram resultado regular (10\%), e um teve resultado insatisfatório (2,5\%). Em longo prazo, dos 18 pacientes que responderam ao questionário, dez deambularam, mesmo que com apoio, no primeiro trimestre após a cirurgia (55,6\%). Conclusâo: nosso estudo mostrou que o perfil dos pacientes com trauma de membros inferiores que necessitaram de reconstrução cirúrgica foi representado por homens jovens, envolvidos em acidentes motociclísticos, durante situação de lazer, sendo o terço distal da perna a região mais acometida. A enxertia foi a técnica mais utilizada para reconstrução e a avaliação funcional pós-operatória demonstrou que, apesar de lesões complexas, a maioria dos pacientes evoluiu com processo de cicatrização favorável e sucesso na evolução funcional.
\end{abstract}

Descritores: Extremidade Inferior. Ferimentos e Lesões. Escala de Gravidade do Ferimento. Cirurgia Plástica.

\section{REFERENCES}

1. Coltro PS, Ferreira MC, Batista BPSN, Nakamoto HA, Milcheski DA, Tuma Júnior P. Atuação da Cirurgia Plástica no tratamento de feridas complexas. Rev Col Bras Cir. 2011; 38(6):381-6.

2. Fairbanks GA, Murphy RX Jr, Wasser TE, Morrisey WM. Patterns and implications of lower extremity injuries in a community level I trauma center. Ann Plast Surg. 2004;53(4):373-7.

3. Aldea PA, Shaw WW. The evolution of the surgical management of severe lower extremity trauma. Cin Plast Surg. 1986;13(4):549-69.

4. Byrd HS. Lower extremity reconstruction. In: Selected Readings in Plastic Surgery. Dallas: Baylor University Medical Center; 1990. v.5. p.1-26.

5. Durrani CA, Mackey SP. Orthoplastic classification systems: the good, the bad, and the ungainly. Ann Plast Surg. 2011;66(1):9-12.

6. Daniel RK, Taylor Gl. Distant tranfer of an island flap by microvascular anastomoses. A clinical technique. Plast Reconstr Surg. 1973;52)2):111-7.

7. Franco D, D`Avila F, Arnaut Júnior M, D’Avila B, Franco T. Tratamento das áreas cruentas de perna com retaIhos locais. Rev Bras Cir Plást. 2015;30(2):264-9.

8. Whitaker IS, Rozen WM, Shokrollahi K. The manage- ment of open lower limb fractures: the journey from amputation to evidence-based reconstruction and harpsichords. Ann Plast Surg. 2011;66(1):3-5.

9. Reddy V, Stevenson TR. MOC-PS (SM) CME article: lower extremity reconstruction. Plast Reconstr Surg. 2008;121(4 Suppl):1-7.

10. Guerra MTE, Thober TA, Bigolin AV, Souza MP, Echeveste S. Fratura do quadril: avaliação pós-operatória do resultado clínico e funcional. Rev bras ortop. 2010;45(6):577-82.

11. Santos MC, Tibola J, Marques CMG. Tradução, revalidação e confiabilidade da Escala de Cicatrização de Vancouver para língua portuguesa - Brasil. Rev Bras Queimaduras. 2014;13(1):26-30.

12. Guimarães RP, Alves DPL, Silva GB, Bittar ST, Ono $N K$, Honda $E$, et al. Tradução e adaptação transcultural do instrumento de avaliação do quadril "Harris Hip Score". Acta ortop bras. 2010;18(3):142-7.

13. MacKenzie EJ, Morris JA Jr, Smith GS, Fahey M. Acute hospital costs of trauma in the United States: implications for regionalized systems of care. J Trauma. 1990;30(9):1096-101; discussion 1101-3.

14. MacKenzie EJ, Morris JA Jr, Jurkovich GJ, Yasui $Y$, Cushing BM, Burgess AR, et al. Return to work following injury: the role of economic, social, and job-related factors. Am J Public Health. 1998;88(11):1630-7. 
15. Graves EJ, Gillum BS. Detailed diagnoses and procedures, National Hospital Discharge Survey, 1994. Vital Health Stat. 1997;(127):1-145.

16. Byrd HS, Cierny G 3rd, Tebbets JB. The management of open tibial fractures with associated soft-tissue loss: external pin fixation with early flap coverage. Plast Reconstr Surg. 1981;68(1):73-82.

17. Byrd HS, Spicer TE, Cierney G 3rd. Management of open tibial fractures. Plast Reconstr Surg. 1985;76(5):719-30.

18. Godina M. Early microsurgical reconstruction of complex trauma of the extremitites. Plast Reconstr Surg. 1986;78(3):285-92.

19. Yaremchuck MJ. Acute management of severe soft-tissue damage accompanying open fractures of the lower extremity. Clin Plast Surg. 1986;13(4):621-32.

20. Yaremchuck MJ, Brumback RJ, Manson PN, Burgess AR, Poka A, Weiland AJ. Acute and definitive management of traumatic osteocutaneous defects of the lower extremity. Plast Reconstr Surg. 1987;80(1):1-14.

21. Chan JK, Harry L, Williams G, Nanchadal J. Soft-tissue reconstruction of open fractures of the lower limb: muscle versus fasciocutaneous flaps. Plast Reconstr Surg. 2012;130(2):284e-95e.
22. Parrett BM, Matros E, Pribaz JJ, Orgill DP. Lower extremity trauma: trends in the management of soft-tissue reconstruction of open tibia-fibula fractures. Plast Reconstr Surg. 2006; 117(4):1315-22; discussion 1323-4.

23. Follmar KE, Baccarani $A$, Baumeister SP, Levin LS, Erdmann D. The distally based sural flap. Plast Reconstr Surg. 2007;119(6):138e-48e.

24. d’Avila F, Franco D, d’Avila B, Arnaut Júnior M. Uso de retalhos musculares locais para cobertura de exposições ósseas na perna. Rev Col Bras Cir. 2014;41(6):434-9.

25. Kneser U, Bach AD, Polykandriotis E, Kopp J, Horch RE. Delayed reverse sural flap for staged reconstruction of the foot and lower leg. Plast Reconstr Surg. 2005;116(7):1910-7.

Received in: 22/08/2016

Accepted for publication: 03/11/2016

Conflict of interest: none.

Source of funding: none.

\section{Mailing address:}

Jefferson Lessa Soares Macedo

E-mail: jlsmacedo@yahoo.com.br scrmacedo@yahho.com.br 